\title{
Role of Co-operative Banks in Financial Inclusion: A Study in the Post Reform Period.
}

\author{
Princy P James \\ Research Scholar, Department of Economics, B K College Amalagiri,Kottayam,686561.
}

\begin{abstract}
Financial inclusion is important because it is necessary condition for sustaining equitable growth. In India marginals and weaker sections are excluded from main stream of the economy. To achieve sustainable development, all sections of the people need to be come into main stream. The process of ensuring access to financial services and timely and adequate credit where needed by vulnerable groups such as weaker sections and low income groups at an affordable cost ( The Committee on Financial Inclusion -Chairman: Dr. C. Rangarajan, 2008). Financial inclusion gives a big push to agricultural sector and marginalised people. The instrument of financial inclusion can be used properly by banking sector in agricultural sector. Then both are interlinked or interrelated. Co-operative banks have rural experience and very good network in rural areas and also having rural orientation. This study attempts to find out the role co-operative banks in financial inclusion in the post reform period.
\end{abstract}

Key words: -Financial inclusion, Financial exclusion, banking sector,co-operative banks, Banking Access, Endogenous growth theory, Credit Flow.

\section{INTRODUCTION}

India has completed 12th five year plan (NITI Aayog replaced planning commission) in 2017. The basic objective of 12th plan is "Faster, More Inclusive and Sustainable Growth". In the new era, service sector plays a crucial role, giving largest share to GDP (52\%). At the same time agriculture sector accommodates $54.6 \%$ of labour force of Indian economy. Indian agriculture sector experiences vicious circle of poverty. In order to break vicious circle of poverty, financial inclusion is needed. Financial inclusion gives a big push to agricultural sector and marginalised people. The instrument of financial inclusion can be used properly by banking sector in agricultural sector. Then both are interlinked or interrelated Commercial banks are ultimately urban in their orientation. However co-operative banks have rural experience and very good network in rural areas and also having rural orientation. This study attempts to find out the role co-operative banks in financial inclusion in the post reform period.Review of Literature K.C Shekhar and LekshmiShekharobserves "The Cooperative banking system in India is characterised by a relatively comprehensive network extending to the grass root level. What distinguishes the co-operative banking sector from commercial banking sector is the focus of the former on the local population and micro-banking among middle and low income strata of the society." AccordingtoaushikBasu and AnnemieMaertens "financial inclusion is important because it is necessary condition for sustaining equitable growth." “ The process of ensuring access to financial services and timely and adequate credit where needed by vulnerable groups such as weaker sections and low income groups at an affordable cost" ( The Committee on Financial Inclusion -Chairman: Dr. C. Rangarajan, 2008)

Objectives and MethodologyTwo major objectives of the study are to find out the role co-operative banks in financial inclusion and to examine how financial inclusion accelerate rural development. This study is based on the secondary data, collected from various books, journals, published government documents, websites etc.

Financial Inclusion - Multidimensional AspectThe term "financial inclusion" has gained importance since the early 2000s, a result of findings about financial exclusion. Financial inclusion or inclusive financing is the delivery of financial services at affordable costs to sections of disadvantaged and low-income segments of society, in contrast to financial exclusion where those services are not available or affordable. As per RBI defines "Financial Inclusion is the process of ensuring access to appropriate financial products and services needed by all sections of the society in general and vulnerable groups such as weaker sections and low income groups in particular at an affordable cost in a fair and transparent manner by mainstream institutional players"

Alfred Hannig- Executive Director of AFI, says "Financial inclusion is no longer a fringe subject. It is now recognized as an important part of the mainstream thinking on economic development based on country leadership." 
The Alliance for Financial Inclusion (AFI) is the world's largest and most prominent network of financial inclusion policymakers from developing and emerging economies who work together to increase access to appropriate financial services for the poor. AFI was founded in 2008 and has grown to more than 105 institutions from 88 member nations from 2008 to 2013.

Goals of Financial Inclusion

The United Nations defines the goals of financial inclusion as follows:

- access at a reasonable cost for all households to a full range of financial services,

-sound and safe institutions governed by clear regulation and industry performance standards;

- financial and institutional sustainability.

- competition to ensure choice and affordability for clients.

Financial Inclusion in IndiaThe term financial inclusion was first time used in April 2005 in the Annual policy statement presented by Y. Venugopal Reddy and first it is introduced in eleventh five year plan. Top 3 states are Kerala, Andhra Pradesh, Himachal Pradesh. Bottom 3 states are Bihar, Assam, West Bengal.11 of Kerala's 14 districts figure in the top 50 scoring district district in India. Ernakulam is the first financial inclusive district in India. The Financial Inclusion in India has increased by CAGR of 7\% from 2008 to 2013.

Source: CRISIL Inclusix 2013, rbidocs.rbi.org.in

\section{THEORETICAL BACKGROUND}

According to Endogenous growth theory or A.K Model investment in physical capital experience diminishing returns, investment in human capital experience increasing returns. Ultimately developed nations experience constant returns in the long run in accordance with the theory. Implication of the theory in financial inclusion is more relevant. India is high developing country. India has abundant human capital which we are not able to use properly. In order to use these human capital efficiently and to attain development in the long run , investment in human capital is needed. In this context the term financial inclusion occupies its relevance.

Features of Co-operative Banks

- Co-operative banks are basically rural oriented.

- Co-operative banks mainly finance agriculture and allied activities

- The interest rate charged by commercial banks is generally low.

- Generally cost of co-operative banking is relatively low.

- Service and not profit is the main motto of co-operative banks

- Co-operative banking is generally federal in nature.

These features of co-operative banks facilitate financial inclusion.

How Co-operative Banks Facilitate Financial Inclusion

Co-operative banks have very good network in rural areas. The co-operative banks are definitely more suited to bring forward the marginal people like women, farmers and weaker sections into mainstream of the economy. Co-operative banks as an institution is still pertinent and can play very constructive role in meeting the objective of greater degree of financial inclusion. Co-operative banks create opportunities for employment and income generation in the rural areas.They increase accessibility of goods and service, all of which contribute to economic growth .Co-operative banks are firm rooted in their community and are hence more likely to influence it positively. The words of Henry Wolff ensures that, co-operative banks are rural oriented i.e "Co-operative banking is an agency which is in a position to deal with the small man on his own terms accepting the security he has and without drawing the protection of the rich". As compared to nearly 300 scheduled commercial banks, inclusive of regional rural banks ,there were more than 2,000 primary cooperative in the urban co-operative sector and more than 90,000 primary agricultural credit societies in the rural sector at the end of 2002 .

Thus co-operative banks can play a bigger role than regional rural banks in achieving financial inclusion. Role of co-operative banks are very important in the real mile financial inclusion.

Agency-wise Ground Level Credit Flow

Agency 2006-07 2007-08 2008-09 2009-10 2010-11

Growth Rate

\begin{tabular}{|c|c|c|c|c|c|c|c|c|}
\hline & & & & $2006-10$ & & $2009-$ & $2010-$ & \\
\hline Co-operative-banks & 42480 & 48258 & 45966 & 63497 & 70105 & 15.66 & 38.14 & 10.41 \\
\hline egional Rural Banks & 20435 & 25312 & 26765 & 35217 & 43968 & 20.4 & 31.58 & 24.8 \\
\hline Commercial Banks & 166485 & 181058 & 228951 & 285800 & 332706 & 20.01 & 24.83 & 6.4 \\
\hline
\end{tabular}

$\begin{array}{llllllll}\text { Total } & 229400 & 2548658301908 & 384514 & 446779 & 18.91 & 27.36 & 16.19\end{array}$

\# :Compound Annual Growth Rate, ${ }^{*}$ :Percentage change over previous year

Source: Compiled from NABARD, 2010 report 
It is clear from the above table that the amount of cooperative credit in India has increased from 2006-07 to 2008 and suddenly decreased by 2,292 crores in the next year and again increased up to 70,105 crores in the year 2010-11. The compound growth rate of credit for cooperative banks from the year 2006-2010 is 15.66 percent and for Regional Rural Banks and Commercial Banks is 20.4 and 20.01 respectively. The percentage change of cooperative bank credit for the year 2009-10 is 38.14 percent which is higher than regional rural banks (31.58 percent), and commercial banks (24.83percent). Again the percentage change in credit of all the banks has declined for the year 2010-2011, whereas the percentage change of credit for cooperative banks is very massive in comparison to other banks for the current years. It may be due to the stringent licensing policy and entry point norm regulation of Reserve Bank of India

\section{FINDINGS OF THE STUDY}

- Role of co-operative banks is very important than any other banks in financial inclusion. As compared to nearly 300 scheduled commercial banks, inclusive of regional rural banks ,there were more than 2,000 primary co-operative in the urban co-operative sector and more than 90,000 primary agricultural credit societies in the rural sector at the end of 2002.

- The concept of financial inclusion is relevant in modern times in Indian context to accelerate economic development and to increase GDP

- India lives in villages" therefore development process should start from grass root level. The cooperative banks facilitates in this context. . The percentage change of cooperative bank credit for the year 200910 is 38.14 percent which is higher than regional rural banks (31.58 percent), and commercial banks (24.83percent) Limitations of the StudyThe time available for the study is limited. Therefore only secondary data are used for study. The concept of financial inclusion has many impact on different segments economy but present study concentrated only on economic development through rural development.

\section{CONCLUSION}

It is argued that as banking services are in the nature of public goods; the availability of banking and payment services to the entire population without discrimination is the prime objective of financial inclusion. Public sector commercial banks, regional rural banks and co-operative banks are the major institutional lenders in rural areas. By being local in nature cooperative banks have a clear advantage over commercial banks for financial inclusion. The labour costs of cooperative banks are considerably less than that of commercial banks and generally the operating costs are also minimal. Cooperative banks are a feasible option for inclusive growth through rural development by creating opportunity for employment and income generation.

\section{Bibliography}

[1] DeendayalSharm (2010): Principles of Banking, Rajat Publication, Delhi

[2] VijayaragavanIyengar (2007): Introduction to Banking, Excel Books, New Delhi

[3] Gordon and Natarajan (2003): Banking,Theory,Low and Practice, Himalaya publications, Mumbai

[4] Shekhar and LekshmiShekhar (2005): Banking, Theory and Practice, Vikas publishing house, Banglore

[5] Rangarajan (2008), Report of the committee on financial inclusion, government of India

[6] RamachandranV, K and M Swaminathan( 2005):Financial Liberalisation and Rural Credit in India, Tulika Publications, New Delhi

[7] BasuPriya,( 2005)Economic and Political Weekly, Vol. 40, No. 37.

[8] World Bank.2014. Global Financial Development Report: Financial Inclusion. Washington

[9] RanjankumarNayak (2012)" Financial Inclusion through co-operative banks: A feasible solution for inclusive growth" AndraPradesh

[10] Reserve Bank of India (2011) Report of Trend and Progress of Banking in India 2000-11, Mumbai.

[11] Report of the Committee for Financial Sector Reforms, Chaired by Dr.RaghuramRajan,

[12] Planning Commission, Government of India, Financial Inclusion and Banks: Issues and Perspectives", RBI Monthly Bulletin, November 2011. 